\title{
Reineke based guide to manage density in Pinus montezumae stands in Puebla, Mexico
}

\section{Guía basada en Reineke para manejar la densidad en rodales de Pinus montezumae en Puebla, México}

TAMARIT-URIAS, Juan Carlos $\dagger^{* *}$, RODRÍGUEZ-ACOSTA, Melchor and ORDÓÑEZ-PRADO, Casimiro

Instituto Nacional de Investigaciones Forestales Agrícolas y Pecuarias, México.

ID $1^{\text {st }}$ Author: Juan Carlos, Tamarit-Urias / ORC ID: 0000-0003-3597-4510, CVU CONACYT ID: 86510

ID $1^{\text {st }}$ Coauthor: Melchor, Rodríguez-Acosta / ORC ID: 0000-0001-9771-2685, CVU CONACYT ID: 99844

ID $2^{\text {nd }}$ Coauthor: Casimiro, Ordóñez-Prado / ORC ID: 0000-0001-8520-8406, CVU CONACYT ID: 344396

DOI: $10.35429 /$ EJE.2020.13.7.18.25

Received July 21, 2020; Accepted December 5, 2020

\begin{abstract}
Objective: Generate a density management guide (DMG) based on the Reineke density index for even-aged stands of Pinus montezumae in Puebla, Mexico. Methodology: Dasometric information from 90 sampling sites of the Forest Management Unit 2103 of the state of Puebla was processed. Each site was $1,000 \mathrm{~m}^{2}$, circularly, coming from natural stands in high density and competition; all growth conditions and age range were covered. The variables density per hectare $(\mathrm{N})$ and quadratic diameter (Dq) were used to adjust the Reineke density-size model. The technique of linear ordinary least squares (OLS) was compared against that of stochastic frontier regression (SFR); the quality of the adjustments was assessed using statistical and graphic criteria. The self-thinning line was determined and a DMG was constructed defining four zones of Langsaeter growth. Contribution: The SFR technique in its semi-normal mode better defined the limit of the maximum boundary of the observed data. DMG is useful for prescribing thinnings as intermediate silvicultural treatments for stands of the species. The maximum density index for a reference Dq of $25 \mathrm{~cm}$ was 886 trees $^{-1}$.
\end{abstract}

Thinning, Stand density index, Even-aged stands

\begin{abstract}
Resumen
Objetivo: Construir una guía para manejar la densidad (GMD) basado en el índice de densidad de Reineke para rodales coetáneos de Pinus montezumae de Puebla, México. Metodología: Se procesó información dasométrica de 90 sitios de muestreo levantados en la Unidad de Manejo Forestal 2103 del estado de Puebla. Cada sitio fue de $1,000 \mathrm{~m}^{2}$, de forma circular, se levantó en rodales naturales en alta densidad y competencia; se cubrieron todas las condiciones de crecimiento y rango de edad. Las variables densidad por hectárea $(\mathrm{N})$ y diámetro cuadrático $(\mathrm{Dq})$ fueron usadas para ajustar el modelo densidad-tamaño de Reineke. Se comparó la técnica de mínimos cuadrados ordinarios lineales (MCO) contra la de regresión frontera estocástica (RFE); la calidad de los ajustes se evaluó mediante criterios estadísticos y gráficos. Se determinó la línea de autoaclareo y se construyó una GMD definiéndose cuatro zonas de crecimiento de Langsaeter. Contribución: La técnica de RFE en su modalidad semi-normal definió mejor el límite de la frontera máxima de los datos observados. La GMD es útil para prescribir aclareos como tratamientos silvícolas intermedios para rodales de la especie. El índice de densidad máximo para un Dq de referencia de $25 \mathrm{~cm}$ fue de 886 árboles hä ${ }^{-1}$.
\end{abstract}

Aclareos, Índice de densidad del rodal, Rodales coetáneos

Citation: TAMARIT-URIAS, Juan Carlos, RODRÍGUEZ-ACOSTA, Melchor and ORDÓÑEZ-PRADO, Casimiro. Reineke based guide to manage density in Pinus montezumae stands in Puebla, Mexico. ECORFAN Journal-Ecuador. 2020. 7-13 : 18-25.

\footnotetext{
* Correspondence to Autor (E-mail: tamarit.juan@ inifap.gob.mx)

$\dagger$ Researcher contributing as first author.
} 


\section{Introduction}

The guides or diagrams to manage the density (DMG) of stands have the fundamental purpose of regulating the density by means of the application of intermediate cuts, also commonly called thinnings, to help to produce high volume of quality wood in the shortest possible time (Burkhart and Tomé, 2012; Cabrera-Pérez et al., 2019). They are tools to apply quantitative forestry, they are built based on the determination of the self-thinning line (line of maximum density or imminent mortality).

In the determination of the self-thinning line for unspecific contemporary stands, predefined theoretical values are commonly used, such is the case of the Reineke density-size functional relationship, where the value of the parameter that corresponds to the slope was established at -1.605 (Reineke, 1933). In this regard, studies such as that of Pretzsch and Biber (2005), Zhang et al., (2005), Quiñonez-Barraza et al. (2018) and Tamarit-Urias et al., (2019), refer that to determine this line and therefore to construct the respective DMG, the particular allometry of each species must be considered. In this sense, VanderSchaaf and Burkhart (2007) and Comeau et al., (2010), add that the value of this parameter differs significantly between species, so it must be determined for each species and region. To determine this, different adjustment techniques have been proposed to improve the definition of the self-thinning line, among which the linear ordinary least squares and the stochastic frontier regression stand out (Santiago-García et al., 2013; Burkhart and Tomé, 2012; Zhang et al., 2015; Lopes et al., 2016).

Using the function parameters derived from the best estimation technique guarantees that the DMG are powerful tools that allow proper and optimal management of the density of the stands. Density is the main factor that the forester can manipulate to influence the establishment and development of the species of interest, to improve the quality of the wood, the growth rate in diameter and influence the production of the timber volume by redistributing the potential. of growth among the remaining individuals (Daniel et al., 1979; Pretzsch, 2009).
The stand density index (SDI) derived from the Reineke function is used to assess stand density. This index as a measure of relative density and site occupancy indicates the number of trees per hectare for a reference mean cuadratic diameter, which was originally set at a constant theoretical value for any species at 25 $\mathrm{cm}$, the Index expresses the relationship between tree size and stand density.

P. montezumae is an abundant conifer and widely distributed in the transverse Neovolcanic Axis of Mexico, it grows forming pure contemporary stands at an average altitude of $2.500 \mathrm{~m}$ and $800 \mathrm{~mm}$ per year of precipitation, the trees of this taxon reach heights of 25 to 30 $\mathrm{m}$, it is highly important for commercial timber harvesting (Perry, 1991; CONAFOR, 2012). Given its economic relevance, it is necessary to carry out studies aimed at generating quantitative silvicultural tools that contribute to improving the technical management of natural stands with this species.

The objective was to build a guide to manage the density based on the Reineke density index for contemporary stands of $P$. montezumae from Puebla, Mexico, by evaluating the quality of fit of the size-density function by the minimum techniques linear ordinary squares and stochastic frontier regression.

\section{Methodology}

The study was carried out in forest plots of the Forest Management Unit (UMAFOR) 2103 "Teziutlán" region, located in the northeastern part of the state of Puebla, Mexico. The average altitude is $2.220 \mathrm{~m}$, the average annual temperature fluctuates from 12 to $22{ }^{\circ} \mathrm{C}$ and it has Luvisol-type soils. Dasometric information from 90 sampling sites raised in natural stands of $P$. montezumae in a state of high density and competition was processed, which guaranteed to meet the requirement of extreme competition for limited resources (space, water, nutrients and sunlight); all growth conditions and age range were covered. Each site was $1,000 \mathrm{~m}^{2}$, circular in shape. The dasometric variables by site were the density expressed in terms of the number of trees and the average square diameter, later the density was scaled to the hectare level. With both variables the Reineke density-size functional relationship was adjusted. 
The basic statistics of the processed variables are presented in Table 1.

\begin{tabular}{|r|r|r|r|r|r|}
\hline Variable & Min & Max & Average & E. D. & C.V. \\
\hline $\mathrm{N}$ & 190 & 3390 & 910 & 740.4 & 81.4 \\
\hline $\mathrm{Dq}$ & 11.5 & 45.9 & 25.3 & 10.2 & 40.4 \\
\hline $\begin{array}{l}\text { Min: Minimum, Max: Maximum, D.E.: Standard } \\
\text { deviation, C.V.: Coefficient of variation. }\end{array}$ \\
\hline
\end{tabular}

Table 1 Basic descriptive statistics of the analyzed dasometric variables

Source: Own elaboration using sample data

The final database was audited by graphic inspection, corroborating that the variables of interest will present logical graphical behavior in the form of an inverse jota (Figure 1), in this way it was prepared for statistical adjustment by regression.

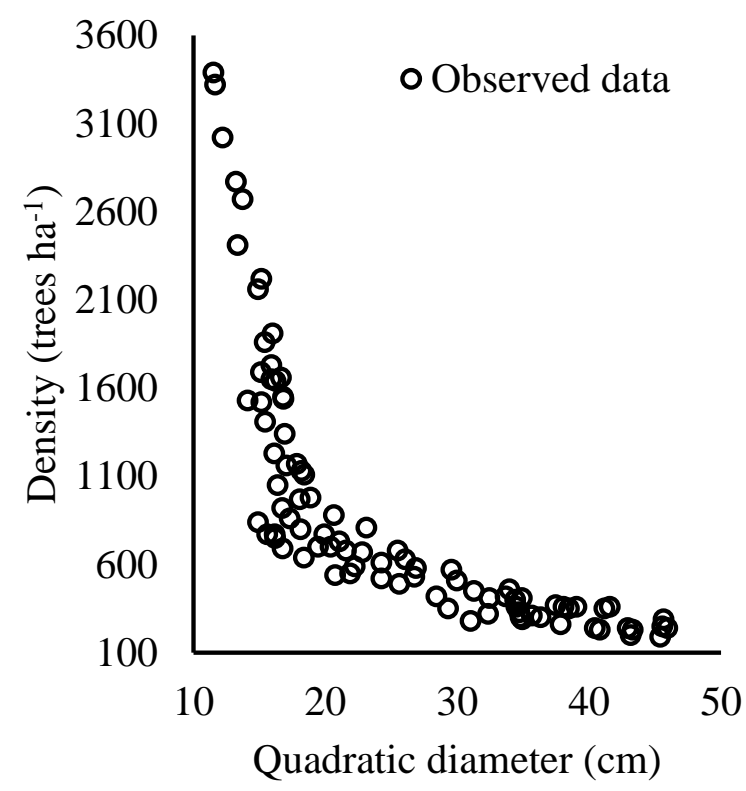

Figure 1 Logical graphical behavior of the variables used in the regression analysis of the Reineke density-size function

Source: own elaboration using the data observed in the experimental sample

The Reineke density-size function expressed linearly when adjusted by the linear ordinary least squares method (OLS-L) had the following linearized mathematical structure:

$$
\operatorname{Ln}(N)=\alpha-\beta \operatorname{Ln}(D q)+\varepsilon
$$

Where: $\mathrm{Ln}$ is the natural logarithm function, $\varepsilon$ is the error term that is distributed as $\varepsilon=\operatorname{idd} \mathrm{N}\left(0, \sigma^{2}\right)$.

When the function was adjusted using the stochastic frontier regression (SFR) econometric technique, the model structure took the form:
$\operatorname{Ln}(N)=\alpha-\beta \operatorname{Ln}(D q)-u+v$

In the SFR the error component is divided into: 1) an error component that accounts for the technical inefficiency in the data $\left(\mathrm{u}_{\mathrm{i}}\right)$ and, 2) an error component associated with the measurement of the individual observations $\left(v_{i}\right)$. ui is an asymmetric term that reflects the technical inefficiency of the observations and is assumed to be distributed independently of $\mathrm{v}_{\mathrm{i}}$ and regressors. $\mathrm{v}_{\mathrm{i}}$ is assumed as a symmetric disturbance distributed independently of $u_{i}$, it collects random variations in production due to factors such as random errors, errors in the observation and measurement of data, it is assumed that it is distributed in the form $\mathrm{v}=$ idd $\mathrm{N}\left(0, \sigma_{\mathrm{v}}^{2}\right)$.

Under these assumptions, statistical distributions are selected for $u_{i}$ that tend to one side, as is the case of the semi-normal and exponential SFR modality. If the value of technical inefficiency $u_{i}$ is assumed to be zero, which is less likely with increasing values of $u_{i}$, then the idd model $\mathrm{N}+\left(0, \sigma_{\mathrm{u}}^{2}\right)$ refers to the seminormal model. If the $\mathrm{u}_{\mathrm{i}}(\mathrm{i}=1 \ldots, \mathrm{N})$ are nonnegative random variables idd $\mathrm{N}+\left(0, \sigma_{\mathrm{u}}^{2}\right)$, then the model is known as the normal-truncated (zero) model (Bi, 2004; Zhang et al., 2005; Pretzsch and Biber, 2005). For the adjustment with SFR, the modalities of Semi-Normal Model (SNM), Truncated Normal Model (TNM) and Exponential Normal Model (ENM) were tested.

In the OLS adjustment, the Model procedure of the SAS / ETS $®$ statistical package (Statistical Analysis System Institute Inc., 2011) version 9.3 was used. When SFR was used, the function was adjusted using the QLIM procedure of the same statistical package and version; in which the maximum likelihood technique is used to estimate the border and the parameter of the technical inefficiency of the observations $\left(u_{i}\right)$. The adjustment of both techniques (OLS-L vs SFR in its three modalities) was compared.

TAMARIT-URIAS, Juan Carlos, RODRÍGUEZ-ACOSTA, Melchor and ORDÓÑEZ-PRADO, Casimiro. Reineke based guide to manage density in Pinus montezumae stands in Puebla, Mexico. ECORFAN Journal-Ecuador. 2020 
The quality of the adjustment by OLS-L was compared with the adjustments obtained when using SFR, the goodness-of-fit statistics used were the likelihood logarithm (logLik), the Akaike information criterion (AIC) and the Schwarz criterion. (SchC), the higher the logLik value and the lower in AIC and SchC the model is more appropriate; as well as the significance of the parameters, the variances of the error components, the ratio of variances of the error components $(\lambda)$ and the total variance $(\sigma)$ (Weiskittel et al., 2009; Comeau et al., 2010; Quiñonez-Barraza et al., 2018). To reinforce the selection criteria, a graphic comparison of the self-thinning lines that each of the adjustment techniques and modalities generated was also performed, in which the behavior of the path of the self-thinning lines superimposed on the observed data was inspected.

With the values of the parameters of the best selected adjustment, the self-thinning line was delimited on a graph on a logarithmic scale, this line corresponds to the maximum number of trees that a hectare without self-thinning can support and is equivalent to $100 \%$ of the SDI, which is express how:

$$
S D I=N\left(D q / D q_{r}\right)^{-\beta}
$$

Where $\mathrm{N}$ is the density, $\mathrm{Dq}$ is the quadratic diameter, Dqr is the reference quadratic diameter, and $\beta$ is the parameter that corresponds to the slope of the function. expressed:

While the quadratic diameter is

$$
D_{q}=\sqrt{(40000 / \pi)(A B / N)}
$$

Where AB is the basal area in $\mathrm{m}^{2} \mathrm{ha}^{-1}, \mathrm{~N}$ is the number of trees $\mathrm{ha}^{-1}$ and $\pi$ is equal to 3.1416 .

Based on Smith et al. (1997) and Gilmore et al. (2005) and based on the maximum density line, assuming a reference Dq of $25 \mathrm{~cm}$, the four different growth areas of Langsaeter were estimated and defined, which make up bands of relative densities.
These zones were determined as a percentage of the maximum SDI; Zone 1, which is underutilized at the site, corresponds to $25 \%$, Zone 2, which is transitional, is defined between $25-35 \%$, Zone 3, which corresponds to maximum growth per hectare, is located between $35-65 \%$, and zone 4 , which is that of self-thinning or eminent mortality, is located between $65-100 \%$.

\section{Results}

The statistical adjustment of the Reineke function when using linear OLS and SFR in its three modalities, shows that in all cases the function parameters are significant (Table 2). However, OLS-L has the drawback that to define the self-thinning line, the value of the intercept must be modified using some subjective approach, this because the fitted line corresponds to the average of the cloud of observed data and not to the upper limit. absolute, which causes the line thus defined in the upper border of the data to be inefficient (Zhang et al., 2005; Santiago-García et al., 2013;

\begin{tabular}{|c|c|c|}
\hline Parameter & \multicolumn{2}{|c|}{$\alpha \quad \beta$} \\
\hline \multicolumn{3}{|l|}{ OLS-L } \\
\hline Estimator & 12.014570 & -1.740140 \\
\hline S.E. & 0.216000 & 0.068040 \\
\hline $\mathrm{T}$ value & 55.62 & -25.58 \\
\hline Significance & $<0.0001$ & $<0.0001$ \\
\hline \multicolumn{3}{|l|}{ SFR-SNM } \\
\hline Estimator & 12.081814 & -1.645050 \\
\hline S. E. & 0.385089 & 0.139818 \\
\hline $\mathrm{T}$ value & 31.37 & -11.77 \\
\hline Significance & $<0.0001$ & $<0.0001$ \\
\hline \multicolumn{3}{|l|}{ SFR-TNM } \\
\hline Estimator & 12.620250 & -1.807118 \\
\hline S. E. & 0.003431 & 0.001081 \\
\hline $\mathrm{T}$ value & 3678.09 & -1671.4 \\
\hline Significance & $<0.0001$ & $<0.0001$ \\
\hline \multicolumn{3}{|l|}{ SFR-ENM } \\
\hline Estimator & 12.546772 & -1.835806 \\
\hline S. E. & 0.210061 & 0.057682 \\
\hline $\mathrm{T}$ value & 59.73 & -31.83 \\
\hline Significance & $<0.0001$ & $<0.0001$ \\
\hline \multicolumn{3}{|c|}{ E.E .: Standard error. } \\
\hline
\end{tabular}
Quiñonez-Barraza et al., 2018).

Table 2 Estimated values of the parameters of the Reineke model by OLS-L and by SFR modality

Source: own elaboration using results of the adjustments 
For this reason, it was decided to select the best quality of fit among the different proven modalities of the SFR technique, which guarantees that a line of the absolute maximum is obtained directly and immediately and that technically it is the correct limit (Bi, 2004; Comeau et al., 2010); In addition, the SFR technique comparatively has the advantage that it estimates extreme values (boundary) of a data set instead of the mean of a function estimated by the OLS method.

The comparative evaluation between the different SFR modalities reveals that the values of the adjustment statistics (logLik, AIC, SchC), the same as the total variance of the error $\left(\sigma^{2}\right)$ and the variance ratio of the error components $(\lambda)$ were similar (Table 3$)$.

\begin{tabular}{|c|c|c|}
\hline Model & Statistical & Value \\
\hline OLS-L & $\sigma^{2}$ & 0.031230 \\
\hline \multirow[t]{5}{*}{ SFR-SNM } & logLik & -19.933630 \\
\hline & AIC & 47.867270 \\
\hline & SchC & 57.866510 \\
\hline & $\sigma^{2}$ & 0.507300 \\
\hline & $\lambda$ & 1.213980 \\
\hline \multirow[t]{5}{*}{ SFR-TNM } & $\log \mathrm{Lik}$ & 4.606700 \\
\hline & AIC & -1.213390 \\
\hline & SchC & 8.785850 \\
\hline & $\sigma^{2}$ & 0.332300 \\
\hline & $\lambda$ & 31536946 \\
\hline \multirow[t]{5}{*}{ SFR-ENM } & $\operatorname{logLik}$ & -2.162250 \\
\hline & AIC & 12.324510 \\
\hline & SchC & 22.323750 \\
\hline & $\sigma^{2}$ & 0.272320 \\
\hline & $\lambda$ & 1.599040 \\
\hline \multicolumn{3}{|c|}{$\begin{array}{l}\text { logLik: logarithm of plausibility; AIC: Akaike } \\
\text { Information Criterion; SchC: Schwarz criterion; } \sigma^{2} \text { : } \\
\text { variance of the error; } \lambda: \text { ratio of variances. }\end{array}$} \\
\hline
\end{tabular}

Table 3 Values of goodness statistics by evaluated adjustment technique.

Source: own elaboration using results of the adjustments of the Reineke function

In all the modalities, significance was detected in the variance of the component of the error relative to the term of technical inefficiency of the observed data.
Although the SFR-SNM model did not present the best values in the adjustment statistics, the comparative graph of the definition of the line of self-thinning (Figure 2) reveals that this modality had the best pattern, since the line fits better. to the upper limit of the border of the observed data and produces the best definition of the maximum border and therefore of the selfthinning line, which is why it was selected to construct the DMD. In this sense, Zhang et al. (2005) points out that this adjustment modality is the most appropriate regression method to estimate the coefficients of the Reineke function and the subsequent line of self-thinning, being possible to use all the available N-Dq information from plots or sites that are locate near an upper limit. The SFR approach to define the line of maximum density has been used in different coniferous and broadleaf species by Weiskittel et al. (2009), Comeau et al. (2010), Reyes-Hernandez et al. (2013), Lopes et al. (2016) and Camacho-Montoya et al. (2018).

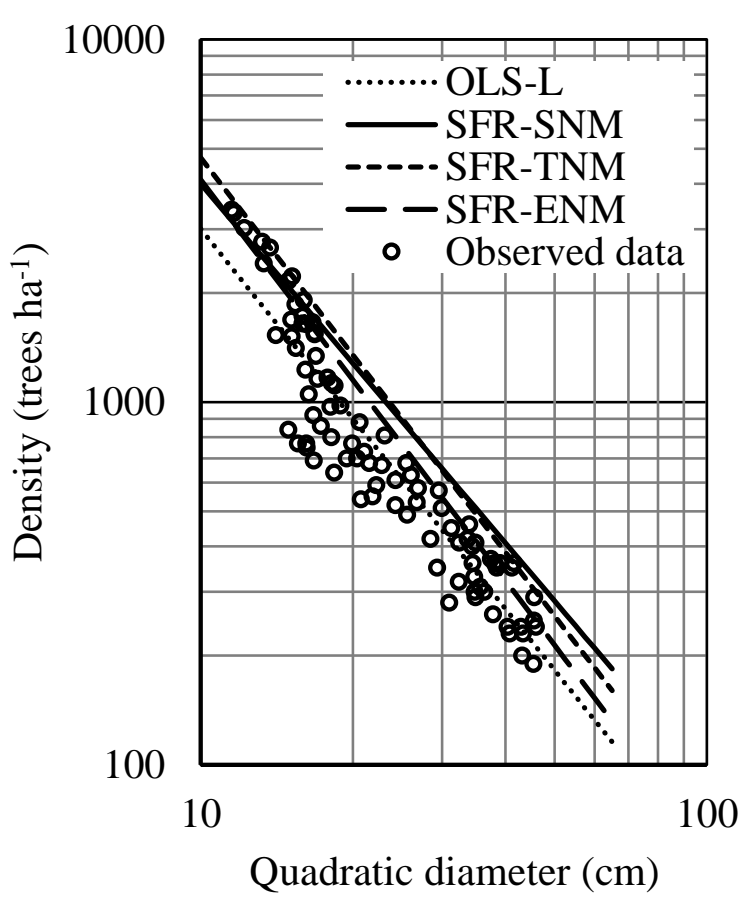

Figure 2 Behavior of the trend of the self-thinning line generated by the evaluated adjustment techniques. Source: data observed in the experimental sample

The Wald test and the likelihood ratio showed that the value of the slope $(\beta)$ of the model estimated using SFR-SNM is statistically different (with $\alpha=0.05$ ) from the theoretical value proposed by Reineke (1933) of -1.605. This result coincides with that reported by Reyes-Hernandez et al. (2013) who used the same adjustment technique and modality in stands of Picea glauca in the Alberta region, Canada, whose slope value was 1.96 . 
The $95 \%$ confidence interval determined for the slope parameter was -1.652 for the lower limit and -1.899 for the upper limit. This interval is similar to that determined by QuiñonezBarraza et al. (2018) from -1.714 to - 1.910 who used the same technique and modality for a group of species of the genus Pinus of Durango, Mexico. In this context, the argument that the slope $(\beta)$ is not always close to the theoretical value and that it can differ significantly between species is confirmed (Comeau et al., 2010; Santiago-García et al., 2013), which is partly due to the fact that different populations present different mortality rates depending on their density, growth habits, factors of site productivity and even the age of the mass (Bi et al., 2000; Weiskittel et al., 2009; ReyesHernandez et al., 2013). This evidence justifies the development of a specific allometry for each species and thus avoid errors when estimating and controlling density (Pretzsch and Biber, 2005).

The maximum SDI estimated with the adjustment of the SFR-SNM when using a $25 \mathrm{~cm}$ quadratic reference diameter (Dqr) was 886 trees $\mathrm{ha}^{-1}$, which is less than that determined by Quiñonez-Barraza et al. (2018) of 1.107 for the same Dqr value in a group of species of the genus Pinus from Durango, Mexico, where he selected the SFR technique in the TNM modality as the best to define the line of self-thinning. In contrast, for the same adjustment modality and the same reference Dq, the maximum SDI determined in this study is similar to that estimated by Martínez (2017) who reports 898 trees $\mathrm{ha}^{-1}$ for mixed Pinus spp forests. in the Zimatlán region, Oaxaca, Mexico.

Based on the self-thinning line and a Dqr $=25 \mathrm{~cm}$, the DMG was constructed for unispecific contemporary stands of $P$. montezumae. The estimated number of trees, which correspond to the limit values in percentage of the SDI that define each line that delimits the growth zones were 225, 310, 575 and 886 trees $\mathrm{ha}^{-1}$ for $25 \%, 35 \%, 65 \%$ and 100 $\%$, respectively; which in turn correspond to the lines of free growth (1), transition (2), maximum growth per hectare (3) and self-thinning (4) (Figure 3).
With information on the mean square diameter and average density per hectare of stands with this species, obtained from sampling sites for timber inventory or derived from a timber growth and yield system, the level of competition can be evaluated and if necessary It is possible to prescribe thinning programs and application intensities in terms of the number of trees per hectare to be removed and its equivalent in $\mathrm{m}^{2} \mathrm{ha}^{-1}$ of basal area $(\mathrm{AB})$.

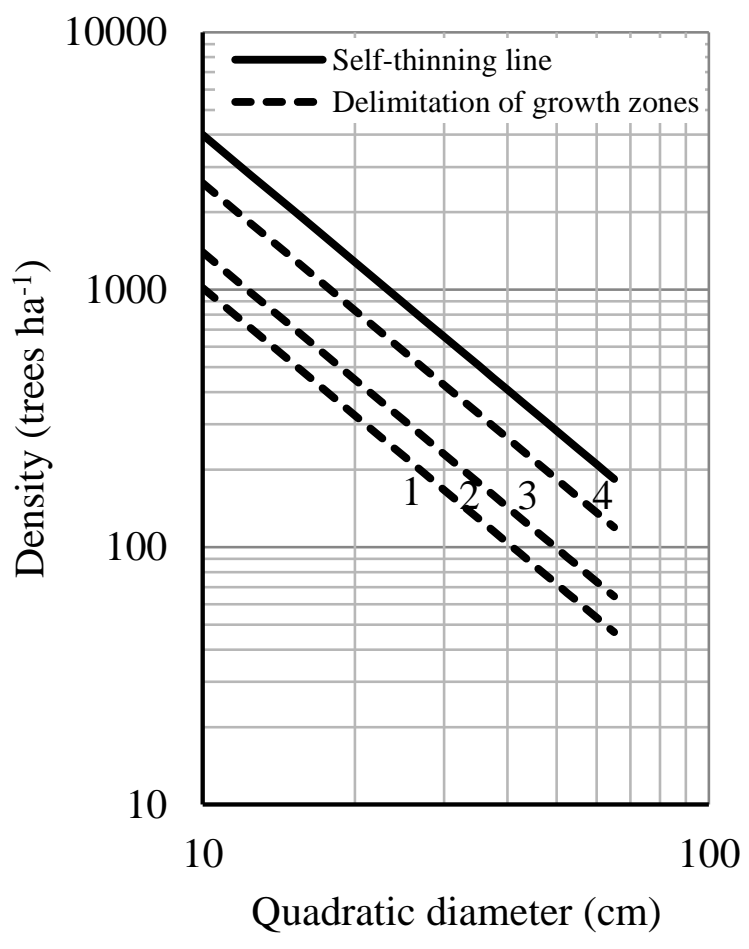

Figure 3 Guide to Density Management based on the Reineke IDR for P. montezumae

Source: own elaboration based on the adjustment of the Reineke model in the RFE-SNM modality

\section{Acknowledgement}

The work of gathering information in the field through sampling sites was financed with fiscal resources from the National Institute of Agricultural Forestry and Livestock Research (INIFAP) assigned to the project with registration number 7352934499 in the Institutional System of Integral Management, under the technical responsibility of the first author. 


\section{Conclusions}

The DMG built based on the Reineke SDI for $P$. montezumae stands at UMAFOR 2103 in Puebla, Mexico, derived from the adjustment by the SFR-SNM technique, is a quantitative silvicultural tool with easy technical and operational application for the forestry professional in charge of the silvicultural management of this species, since it allows you to assess the need to apply thinning. For its reconstruction some program in the form of a spreadsheet such as Microsoft Office ${ }^{\circledR}$ Excel can be used. The DMG will contribute to better applying silvicultural practices through adequate density management, making intermediate cuts as silvicultural treatments and optimizing the commercial shift of the species in the study area.

\section{References}

Bi, H. (2004). Stochastic frontier analysis of a classic self-thinning experiment. Austral Ecology 29(4): 408-417.

Bi, H., Wan G., \& Turvey, N. D. (2000). Estimating the self-thinning boundary line as a density-dependent stochastic biomass frontier. Ecology 81(6), 1477-1483.

Burkhart, H. E., \& Tomé, M. (2012). Modeling forest trees and stands. Springer. New York, NY, USA. 457 p.

Cabrera-Pérez, R. S., Corral-Rivas, S., Quiñonez-Barraza, G., Nájera-Luna, J. A., CruzCobos, F., \& Calderón-Leal, V. H. (2019). Density management diagram for mixed-species forests in the El Salto region, Durango, Mexico. Revista Chapingo Serie Ciencias Forestales y del Ambiente, 25(1), 17-29.

Camacho-Montoya, J. A., Santiago-García, W., Rodríguez-Ortiz, G., Antúnez P., SantiagoGarcía, E., \& Suárez-Mota, M. E. (2018). Autoaclareo y manejo de la densidad en rodales coetáneos de Pinus patula Schiede ex Schlechtdl. \& Cham. Revista Mexicana de Ciencias Forestales, 9(49), 188-212.

Comeau, P. G., White, M., Kerr, G., \& Hale, S. E. (2010). Maximum density-size relationships for Sitka spruce and coastal Douglas-fir in Britain and Canada. Forestry, 83(1), 461-468.
Daniel, T. W., Helms, J. A., \& Baker, F. S. (1979). Principles of silviculture. Second Edition. McGraw-Hill. New York, USA. 500 p.

Lopes, P. E., Calegario, N., Saraiva, G. N., de Almeida, M. E., \& de Almeida, A. J. (2016). Estimate of stand density index for Eucalyptus urophylla using different fit methods. Revista Árvore, 40(5), 921-929.

Martínez, L. J. (1917). Guías de densidad para masas mezcladas de San Pedro El Alto, Zimatlán, Oaxaca. Tesis de Maestría. Colegio de Postgraduados. Campus Montecillo. Montecillo, Texcoco, Edo. de Méx., México. 99 p.

Pretzsch, H., \& Biber, P. (2005). A re-evaluation of Reineke's rule and stand density index. Forest Science, 51(4), 304-320.

Pretzsch, H. (2009). Forest dynamics, growth and yield: from measurement to model. Springer-Verlag Berlin Heidelberg. Germany. $664 \mathrm{p}$.

Quiñonez-Barraza, G., Tamarit-Urias, J. C., Martínez-Salvador, M., García-Cuevas, X., de los Santos-Posadas, H. M., \& Santiago-García, W. (2018). Maximum density and density management diagram for mixed-species forests in Durango, Mexico. Revista Chapingo Serie Ciencias Forestales y del Ambiente, 24(1), 7390.

Reineke, L. H. (1933). Perfecting a stand-density index for even-aged forests. Journal of Agricultural Research, 46, 627-638.

Reyes-Hernandez, V., Comeau, P. G., \& Bokalo, M. (2013). Static and dynamic maximum sizedensity relationships for mixed trembling aspen and white spruce stands in western Canada. Forest Ecology and Management, 289, 300-311.

Santiago-García W., De los Santos-Posadas, H. M., Ángeles-Pérez, G., Valdez-Lazalde, J. R. Del Valle-Paniagua, D. H., \& Corral-Rivas J. J. (2013). Auto-aclareo y guías de densidad para Pinus patula mediante el enfoque de regresión de frontera estocástica. Agrociencia, 47, 75-89.

SAS Institute Inc. (2011). SAS/STAT® 9.3 User's Guide. Cary, NC: SAS Institute Inc. 
Tamarit-Urias, J. C., Quiñonez-Barraza, G., De los Santos-Posadas, H. M., Castañeda-Mendoza, A., \& Santiago-García, W. (2019). Diagrama para manejo de la densidad en rodales de Pinus patula Schiede ex Schltdl. \& Cham. en Puebla, México. Revista Mexicana de Ciencias Forestales, 10(51), 157-181.

VanderSchaaf C. L., \& Burkhart H. E. (2007). Comparison of methods to estimate Reineke's maximum size-density relationship. Forest Science, 53(3), 435-442.

Weiskittel, A., Gould, P., \& Temesgen, H. (2009). Sources of variation in the self-thinning boundary line for three species with varying levels of shade tolerance. Forest Science, 55(1), 84-93.

Yoda, K., Kira. T., Ogawa, H., \& Hozumi, K. (1963). Selfthinning in overcrowded pure stands under cultivated and natural conditions. Journal of Biology Osaka City, 14, 107-129.

Zhang, L., Bi, H., Gove, J. H., \& Heath, L. S. (2005). A comparison of alternative methods for estimating the self-thinning boundary line. Canadian Journal of Forest Research, 35(6), 1507-1514.

Zhang, X., Zhang, J., \& Duan, J. (2015). A hierarchical bayesian model to predict selfthinning line for Chinese fir in southern China. PlosOne, 10(10), e0139788. 